Studia Slavica Savariensia 2016. 1-2. 292-296

DOI: $10.17668 /$ SSS.2016.1-2.292

\title{
Tomislav Krekić
}

(Sambotel, Mađarska)

\section{BUNJEVAČKE FRAZE I POSLOVICE U GARI}

\begin{abstract}
„Sve filozofije završavaju u narodnim poslovicama”
\end{abstract}
Mel Camino

\begin{abstract}
In our short study, we first review the many definitions of proverbs (folks sayings, phrases), then we briefly establish the main characteristics of proverbs and also refer to the issue of the (potentially) common origin of some proverbs. Finally, we classify proverbs into general categories according to their contents, and illustrate the categories with proverbs by used by the southern Slav ( Bunjevac ) population of Gara.
\end{abstract}

Keywords: proverb, Bunjevac, Gara

Kako bismo definirali pojam poslovice? $\mathrm{S}$ jedne strane to je relativno lak zadatak (manje-više mnogi bi znali neku vrstu definicije), a s druge dosta je teško sakupiti sva relevantna obilježja poslovica. Za ilustraciju prikazat ću nekoliko definicija, objašnjenja poslovica te neke primjere koje se mogu pronaći na raznim webstranicama.

„Poslovice su nastale iz iskustva starijih ljudi i naroda i uglavnom govore o međuljudskim odnosima poput prijateljstva i ljubavi. Možda mnoge od njih zvuče kao da uopće nemaju smisla, ali bitno je zapamtiti da poslovice ne treba shvaćati doslovno. Primjerice, nema kruha bez motike, značilo bi da se bez rada i truda ne može ništa dobiti. Uzmimo za drugi primjer poslovicu: odijelo ne čini čovjeka. Ta poslovica zapravo govori o tome da čovjeka ne treba suditi po vanjskom izgledu, već po tome kakav je iznutra. Većina je poslovica takva, tjera nas na razmišljanje.“ (http://narodni.net/stare-narodne-poslovice-inarodne-mudrosti/)

„Poslovica je, s druge strane, sažeta izreka koja izriče životnu mudrost ili mudru misao, ponekad stilski naglašeno (bilo cinično ili duhovito), ili pak pjesnički u rimi. Poslovice postoje na svim jezicima i u svim kulturama, prve pisane nalaze se već u Bibliji, među mudrosnim knjigama Starog zavjeta."(http://documents.tips/documents/skripta-uvod-u-teorijuknjizevnosti.html)

„Mudre izreke i poslovice možete čuti gotovo svakodnevno. Što su to poslovice? Poslovice su fraze u kojima je sažeto nečije životno iskustvo. 
Razmišljajući i uvažavajući poslovice prvenstveno i sami postajemo mudriji, jer je život prekratak da bismo sami napravili sve pogreške i stekli iskustvo, stoga je bolje učiti na tuđim pogreškama.

Poslovica je često izrečena kao preneseno značenje, stoga zahtjeva da o svakoj poslovici razmislimo.

Uzmimo jedan primjer: "Dajte čovjeku ribu - nahranili ste ga za jedan dan; Naučite čovjeka da lovi ribu - nahranili ste ga za cijeli život." - Ovdje se naravno ne misli na nikakve ribe, već je autor ove izreke želio reći da je bolje čovjeka poučiti nego mu pružiti sve već na gotovo. Jer kada smo ga jednom naučili, on više neće toliko trebati našu pomoć. Ovo se posebno može odnositi na roditelje koji pružaju sve gotovo svojoj djeci, te ih na taj način "hendikepiraju" za život." (www.poslovice.org/poslovice/o-poslovicama-stosu-poslovice/)

Iz navedenih se primjera jasno iscrtava da razne definicije poslovica sadrže vrlo slična obilježja, ali se po nekim karakteristika ipak pomalo, iako ne znatno, razlikuju.

Kad se govori o frazemima i poslovicama koje poznaju i koriste Bunjevci, treba spomenuti da je Ambrozije Šarčević već u 19. stoljeću izdao knjigu pod naslovom: Zbirka mudrih i poučnih izrekah. (ŠARČEVIĆ 1869) Na sljedeću zbirku bunjevačkih narodnih poslovica čekalo se gotovo jedno stoljeće. Blaško Rajić, župnik u Subotici još je prije Drugoga svjetskog rata preko Alekse Kokića poslao Antunu Šimčiku sakupljene bunjevačke poslovice. On je te poslovice s objašnjenjima objelodanio 1964. godine, no to već Rajić nije doživio. (ŠIMČIK 1964) Među suvremenijim radovima o bunjevačkim narodnim poslovicama svakako je neizbježan članak Tomislava Žigmanova pod naslovom: Problemi i narav utemeljenja morala u bunjevačkim narodnim poslovicama i izrekama. (ŽIGMANOV 2001: 359-371)

Najočiglednija i najupadljivija karakteristika poslovice, pa i frazema, jest da su to izrazi koji se sastoji od više riječi. One su ustaljene, učvršćene sintagme, kolokacije koje manje-više osjećamo zaokruženom, cjelovitom jedinicom. S druge strane, poslovični fond, poslovičko blago (zbog svog, recimo, narodnog karaktera) u trajnoj je promjeni, stalno se mijenja. Jednim se dijelom obogaćuje uvijek novim elementima, a drugim dijelom, iako snaga očuvanja jezika kao magnet utječe na elemente zalihe izražavanja, neprekidno izbacuje iz sebe one izraze koji zbog nečega izgube svoju aktualnost i postaju zastarjeli. Ako se spominje narodna oslika, obilježje poslovica postavlja se pitanje podrijetla, to jest je li riječ o tvorevini našeg naroda ili se radi o prijevodu iz nekog drugog jezika. Gotovo sigurno možemo tvrditi da ima takvih izraza koji su karakteristični za naš jezik, no za dobar dio fraza i poslovica koje nam se čine na prvi pogled izrazito našima, $s$ vremenom se ispostavlja da im postoji točan prijevod u drugim jezicima. Slijedeće poslovice postoje i u mađarskom jeziku: gluv je ko top, ima usta ko Bečka kapija, iz lude jame ludi viter duše, jedna lasta ne pravi proliće, nije zlato sve što sja, nova metla dobro mete, nužda zakon minja. Općenito možemo reći da našem slučaju obično dolazi u obzir 
mađarski i njemački jezik. Ipak podudaranje s nekim drugim jezikom još ne znači da je neka fraza ili poslovica posuđenica. U dva ili više naroda - na osnovi istog pristupa - mogla je nastati identična fraza bez toga da je bilo koji narod preveo na svoj jezik neki sličan izraz (na primjer: voditi koga za nos). Prema Gáboru O. Nagy, iako postoji adekvatan, odgovarajući ekvivalent u mnogim indoeuropskim jezicima (između ostalog u latinskom, talijanskom, francuskom, njemačkom, engleskom, ruskim, hrvatskim, srpskim, bugarskim, mađarskim), i vjerojatno još mnogim jezicima, ipak ne možemo sa sigurnošću tvrditi da je putem prevođenja dospjela iz jednog jezika u drugi. Naime, pristup odakle i ova fraza nastaje - slika medvjeda, bika ili druge divlje životinje s karikom u nosu- isto jetako mogao biti izvor fraze pri jednom ili drugom narodu. (O. NAGY 2010: 10)

Unatoč takvoj mogućnosti, ipak se čini vjerojatnim da su fraze i poslovice koje postoje u više naroda dospjele pomoću kulturnih veza od jednog naroda do drugog. Zbog toga je očito da narodnosno obilježje nije odlika koja odvaja jedan narod od drugog. Međutim, u tomu što je i kako jedan narod preuzeo od izraza susjednog naroda ili međunarodnog poslovičnoga blaga,iscrtava se njegov način razmišljanja i shvaćanja, njegova jezična mašta, karakteristika stilske potrebe.

Postoje fraze i poslovice koje se upotrebljavaju samo u nekom određenom kraju, čije korištenje ne prelazi granice neke geografske jedinice. Na primjer, za bačvanske je Bunjevce karakteristično da spominju frazu: zdrav ko puce.

Odnos fraze i poslovice uzimajući u obzir njihovu ulogu u govoru mogli bismo opisati paralelom riječi i rečenice. Fraze imaju vrijednost riječi, njihovo se značenje može opisati jednom riječju, dok poslovice obično imaju funkciju rečenice, to jest i sama poslovica izražava govornikov odnos prema stvarnosti. Dakle, ne radi se samo o tome da su poslovice formalno potpune rečenice, jer u tom smislu i fraza može biti čitava rečenica. (O. NAGY 2010: 12)

Fraza je u većini slučajeva neka vrsta aluzije, dok je poslovica načelo, princip, životna mudrost korištena sa zahtjevom osnovne vrijednosti, savjet, presuda ili mišljenje. Poslovice za razliku od fraza nisu samo jezična i stilistička sredstva govora već izražavaju i misli. Obično se naglašava da su izrazi čovjekovih stoljetnih opažanja, životnih pravila, moralnih presuda u kratkom, upadljivom obliku. Zbog toga su vjerni izražaji načina razmišljanja, mentaliteta nekog naroda. Iako, uzimajući u obzir njihov broj, odnose se na relativno mali broj bezbrojno mnogih pojava života, po procjeni nekih oko tristo pojava, nije lako odrediti najvažnije tematske krugove u koje bismo mogli uvrstiti poslovice u smislu sadržaja. Većina klasifikacija određuje uglavnom sljedeća područja: poslovice u svezi općih odnosa, koje se odnose na neku ljudsku djelatnost ili odnos, pravila u svezi s bavljenjem poljoprivredom, vremenske prognoze, zdravstveni savjeti i konvencionalni izrazi. (O. NAGY 2010: 15-16)

Slijede poslovice i izreke uvrštene po već spomenutim kategorijama. Jedan dio primjera je iz svojeg sakupljanja, a drugi iz knjige Garski Bunjevci, (pod 
podnaslovom Bunjevačke polovice i izreke) koje su plod sakupljačkog rada Mariške Patarčić-Kubatov. (GARSKI BUNJEVCI 2012) Ukupno je sakupljeno oko 600 poslovica, samo jedan manji dio ih je naveden kao primjer u već spomenute kategorije.

1. Najveći broj poslovica sadrži ustanovljavanje, presudu ili savjet koji je vezan s čovjekom kao članom društva, odnosno s tipom, grupom ljudi ili s nekom pojavom, očitovanjem, djelatnošću u općenitom smislu.

1/a Unutar tog tipa razlikujemo potpuno općenite poslovice: Ako ne možemo kako oćemo, onda ćemo kako možemo, Batina ima dva kraja, Bez zdravlja nema bogatstva, Bilo, pa prošlo, Čovik brez slobode ko riba brez vode, Da rakija nije dobra, ljudi bi već davno zaboravili kako se peče, Gdi je mnogo riči, tamo je malo koristi, I blato je dio rodne grude.

1/b Ima i takvih koje se odnose na neko područje života, na primjer na rad: Brez alata nema ni zanata, Brez orača i kopača nem a kruva, ni kolača, Lako je divanit, al' je teško radit, Ne radu vridni, već silni (mnogi), Tko radi, ne boji se gladi, Tko radi, taj zaradi.

1/c Ima mnogo poslovica koje slikovito opisuju različite tipove ljudskih odnosa (prijateljstvo, bračni odnos, susjedstvo itd.): Ako čeljad nisu bisna, kuća nije tisna, Baba šumom, dida drumom, Bivši prijatelj gorji je od neprijatelja, Bolja je i najgora mater, neg' najbolja maćuva, Brat je mio, ma kakve vire bio, Čuvaj se čovika, koji je pročitao samo jednu knjigu, I rođenog oca bi za novce prodo, Kaži Jakovu, Jakov će svakomu, Nepozvanom gostu misto za vrati, Nije svako čovik, zato što gaće nosi.

1/d Neke poslovice se odnose na odgoj: Ako imaš mana, popravi se, ako ji nemaš, čuvaj ji se, Ako ne možeš biti slavan i bogat, možeš biti pošten i dobar, Ako oćemo da nas svit voli, onda i mi moramo svit voliti, Ako u mladosti nisi naučio, žalit ćeš u starosti, Bez muke nema nauke, Čuvaj mladost za starost.

1/e U posebnu smo skupinu uvrstili poslovice koje spominju Boga: Bog ne plaća svaki dan, Bog nije nagal, al' je dostižan, Bog nikom dužan ne ostane, Gdi se stariji ne čuju, tu Bog ne pomaže, Kako Bog odredi, onako je najbolje, Malo radi, malo kradi, a malo će ti Bog pomoći, Pijanog i Bog čuva, Pomozi drugim, i tebi će Bog pomoći, Sloga od Boga, a nesloga od zloba.

2. U posebni tip poslovica pripadaju pravila $\mathrm{u}$ svezi $\mathrm{s}$ bavljenjem poljoprivredom. One se zanimaju za seljački život, zemljoradnju, stočarstvo, problem pokućstva: Ako lito ne dade, zima nema čega, Bolje danas jaje, neg sutra kokoš, Dobar konj el ošanta, el oćoravi, I u rđavom buretu mož bit dobro vino, Jesen je bogata, a zima je rogata, Kako posiješ, onako ćeš i požnjeti, 
Koja kokoš puno kotkodače, malo jaja snese, Nema žita bez kukolja, Vinograd ne ište molitve, već motike.

3. Uzevši u ozbir prvobitno korištenje, bliski su već spomenutoj grupi poslovice koje su u svezi s vremenom, osobite su vrste neke vremenske prognoze: Jesen je bogata, a zima rogata, Klara grožđe šara, Sveta Kata, snig za vrata.

4. U krug drevne, narodne znanosti spadaju poslovice koje govore o zdravlju: Bez zdravlja nema bogatsva, Bolest na konju dolazi, a na pužu odlazi, Bolestan se pita, a zdrav se nudi, Čistoća je pola zdravlja, Dok je čovik zdrav, $i$ voda mu je slatka, Gdi neznanje caruje, bolest blaguje, Gdi razum vlada, tilo ne strada, Ko puši, zdravlje ruši, Lakše je spričiti, nego ličiti, Tko suncu pendžere zatvara, bolesti vrata otvara, Tko zdravlje voli, ritko oboli, $U$ zdravom tilu zdrava je i duša, Zdravlje je najveće bogatsvo.

5. U krug konvencionalnih izraza pripadaju one poslovice kojima je najuočljivija crta da ih navika drži u životu, spominju se u nekim slučajevima, nekom prigodom, bez toga da bismo im pridavali veći značaj: Ako bog da $i$ Gospa će, Ako ne curi, a ono kapa, Bilo, pa prošlo, Kud koji, mili moji.

U ovom smo kratkom izlaganju htjeli tek privući pažnju na bunjevačke narodne poslovice $\mathrm{i}$ frazeme koje se još manje-više koriste u bačvanskom naselju, Gari. Njihova podrobnija obrada i analiza bila bi zadaća nekog većeg, opsežnijeg sustavnog rada.

\section{Literatura}

GARSKI BUNJEVCI = Garski Bunjevci. Gara: Hrvatska samouprava Gara, 2012.

O. NAGY $2010=$ O. NAGY G. Magyar szólások és közmondások. Budapest: Akkord, 2010.

ŠARČEVIĆ 1869 = ŠARČEVIĆ A. Zbirka mudrih i poučnih izrekah. Subotica, 1869.

ŠIMČIK 1964 = ŠIMČIK A. Bunjevačke poslovice Blaška Rajića // Zbornik za narodni život i običaje Južnih Slavena. Knjiga 42. Zagreb: JAZU, 1964. 475-487.

ŽIGMANOV $2001=$ ŽIGMANOV T. Problemi i narav utemeljenja morala $\mathrm{u}$ bunjevačkim narodnim poslovicama i izrekama // Obnovljeni život: časopis za filozofiju i religijske znanosti, 2001. Vol. 56, No.3. 359-371.

http://documents.tips/documents/skripta-uvod-u-teoriju-knjizevnosti.html Pristup ostvaren: 06.10.2016.

http://narodni.net/stare-narodne-poslovice-i-narodne-mudrosti// Pristup ostvaren: 08.10.2016.

www.poslovice.org/poslovice/o-poslovicama-sto-su-poslovice/ Pristup ostvaren: 08.10.2016. 